\title{
Alone and Anxious: Addiction to Work as an Adaptation to Postmodern Dislocation
}

\author{
Anna Buhrmann
}

\section{INTRODUCTION}

$\mathrm{T}^{\mathrm{H}}$ HE majority of Canadians work upwards of forty-five hours per week, and nearly one third of Canadians identify themselves as being addicted to work (Duxbury \& Higgins, 2013, p. 6; Keown, 2008, p. 28). This essay investigates the question: to what extent does the concept of addiction to work shed light on society's anxieties? By examining values underpinning the free market economy and how they affect the daily rhythm of human life, I argue that the pressures of postmodern life dislocate individuals within their social context. In a need to alleviate the anxieties stemming from this instability, individuals often work excessively to establish a sense of identity and security. An unbalanced amount of work, however, exacerbates not only a person's fears but their compulsivity to work, multiplying the detrimental effects on their daily lives. In sum, because workaholism further distances us from social rootedness, it is crucial to question cultural acceptance of excessive focus and time spent on work.

\section{Alone and Anxious: Addiction to Work as an Adaptation to Postmodern Dislo- CATION}

Rob Dubé is a confessed workaholic. He wakes up at 5:45 a.m. and grabs coffee on the road to the first of his two offices. He sometimes drives with his left knee on his commute since that frees him to check his emails and leave voicemails. He shares: "I thrive in chaos... the crazier it gets, the more budget cutbacks there are, the more restrictive timelines are, the more unrealistic the workload, the better I can do. And in a totally sick way I love it" (Menzies, 2005, pp. 76-77).

As an individual with an excessive drive to work, Rob has plenty of company in our society (Killinger, 1991). ${ }^{1}$ To be fair, not every workaholic exhibits such an extreme lifestyle. Additionally, a compulsive, consuming need to work is not the only reason why someone may be working long hours (Ksiazak, 2014). A definition given by a recent review of workaholism literature illuminates what, exactly, this term signifies:

an addiction to work that involves feeling compelled or driven to work because of internal pressures, having persistent and frequent thoughts about work when not working, and working beyond what is reasonably expected (as established by the re-

\footnotetext{
${ }^{1}$ Due to the limited scope of this paper, I will focus on the implications of the concept of addiction to work within a specifically Canadian context.
} 
quirements of the job or basic economic needs) despite potential negative consequences (Clark, Michel, Zhdanova, Pui, \& Baltes, 2016, p. 1840).

The review found that, rather than being associated with better performance or greater satisfaction with employment, workaholism was related to "burnout, job stress, lower job satisfaction, and poorer emotional/mental and physical well-being." More unexpectedly, instead of raising the profitability of their employers, workaholics may actually cost them more due to reduced health (p. 1864). In Canada, the average hours of work in a week has been rising since 1991, with $68 \%$ of men and $54 \%$ of women putting in upwards of 45 hours per week (Duxbury \& Higgins, 2013, p. 6). Disquietingly, the most recent numbers from Statistics Canada indicate that nearly one third of working Canadians between the ages of 19 and 64 self-identify as workaholics, a proportion which has not shifted since 1992, when data on the subject was first collected (Keown, 2008, p. 28). ${ }^{2}$

The concept of an addiction to work has garnered some response. For example, those afflicted might be diagnosed on the Bergen Work Addiction Scale (BWAS) by a clinician and receive therapy (Andreassen, Griffiths, Hetland, \& Pallesen, 2012; Andreassen, 2013, p. 7). Alternatively, workaholics might opt to join Workaholics Anonymous, an organization modelled after Alcoholics Anonymous whose purpose is to share a message of recuperation with suffering workaholics (2018). However, overall movement towards addressing workaholism is limited, which is especially surprising considering how work dominates our daily lives and how many of us perceive it as an addiction. Why are we not more curious about investigating the nature of work in our society, and its potential to develop into a harmful, compulsive behaviour? This hes- itation suggests that the root of the problem may lie closer to home than we would prefer - in short, we are all too busy working to talk about it.

In this essay, I will argue that examining the addiction to work sheds light on the causes and consequences of our society's unspoken anxieties. These anxieties are collective apprehensions about the meaning and security of our lives that are difficult to locate as the dimensions and demands of our postmodern world continuously shift under the dictates of free markets. As technological advancement and the acceleration of time pressure us into increasing isolation, devoting more time and energy to our jobs can become a coping mechanism for our anxieties, pulling us further into an addiction that decreases our personal health and social rootedness, yet multiplies our fears.

\section{I: An Age of Dislocation}

Karl Marx (as cited in Crary, 2013, p. 64) noted in 1858 that "capital by its nature drives beyond every spatial barrier." His prediction strikes a chord in our incessantly enlarging world (Crary, 2013, p. 8), where "lives... are made and unmade according to the dictates and whims of the market" (Berlant, 2011, p. 192), and "carefully engineered management, advertising, and mass media indoctrination keep people performing their market functions at an optimal rate" (Alexander, 2001 p. 9). In recent decades, the pace of technological change has heightened the extent to which an individual is dislocated in space and time (Hassan 2009). As Jonathan Crary notes, the ceaseless functioning of economic and information systems permits uninterrupted modelling of communal and personal identity. Consequently, the individual lives in a constantly disorienting environment that "has the semblance of a social world, but. . is actually

\footnotetext{
${ }^{2}$ As far as I could find, this survey, which relied on the self-identification of participants, is the only source of statistics describing rates of workaholism in Canada. The rarity of data signifies a lack of recognition of addiction to work in our social context, and this arguably unreliable method of collecting data suggests that we only find the concept of an addiction to work meaningful when it impacts us on an individual level. Workaholism, therefore, may be highly likely to be viewed as inconsequential in the public sphere.
} 
a non-social model of machine performance and a suspension of living that does not disclose the human cost required to sustain its effectiveness" (9). In sum, the rhythms of the market reshape the ground under our feet while we attempt to remain standing in a shifting postmodern world.

The ensuing expense to the individual unfolds daily in the absence of time to reflect, plan, socialize, and attend to personal well-being (Hassan 2009, p. 107). As a result, market forces "deliberately [undermine] the countervailing influences of social structures that spontaneously arise in offices, factories, modern families, etc." (Alexander, 2001, p. 9). The loss of "rootedness in the rhythm of and rituals of shared time and space" results in the systematic curtailing of "myriad intimate ties between people and groups" (Menzies, 2005, p. 85; Alexander, 2001, p. 1). Professor Bruce Alexander, who argues that disorientation necessarily precedes addiction (2001, p. 5), labels these shifts as a "universal dislocation" (p. 4) that sets the stage not only for a "generalized pathology of anxiety" (Hassan, 2009, p. 107) but for broad-sweeping addictions that attempt to make life at least liveable, given the conditions. Among potential substitute lifestyles, a compulsion to relentless work offers a relatively profitable mechanism for coping with the demands of postmodernity.

\section{II: Workaholism AS A Substitute LIFESTYLE}

A consuming devotion to work flows from the anxiety-inducing conditions experienced by those subject to the pressures of technology and the free market. For instance, the security of jobs in Canada is increasingly volatile. Francis Fong, the Chief Economist of Chartered Professional Accountants Canada, noted in a recent report that "increasingly full-time, full-year work is giving way to more precarious arrangements that lack the same pay, benefits, and protections enjoyed by previous generations" (2018, p. $2)$. Indeed, the drive of employees to work hard despite these conditions reveals concerns about instability (Hassan, 2009, p. 106).
Furthermore, the around-the-clock nature of trading on the stock market, and thus the economy, normalizes labouring without interruption or boundaries (Crary, 2009, p. 10). The mobility of technology compounds employment demands by blurring spaces and time devoted to work with the rest of the life of the employee. For instance, the 2012 National Study on Balancing Work and Caregiving in Canada found that more than half of those surveyed supplement their normal job hours with weekends and evenings spent completing work at home. (Duxbury \& Higgins, 2013, p. 4). Notably, this practice panders to workaholics (Stearns, 2008, p. 166). With incessant email notifications, phone calls, and digital to-do reminders, the present becomes an opportunity for perpetual productivity, increasing compulsion to work, as well as the anxiety of spending time away from it (Menzies 2005).

Not only does a need to be excessively productive stem from the troubling omnipresence of work, but it also reflects deeper concerns relating to our unstable identities as dislocated people. Our worth, in the eyes of others, is heavily defined by what we do. It is telling that Global Affairs Canada advises the following to newcomers to Canada looking for conversation starters: "the first question on first contact will be: what do you do? Work/occupation is important to Canadians, and it is also a social marker; it is what separates and defines a person in relation to another" (Centre for Intercultural Learning, 2018, para. 2). Alexander draws attention to how occupational pursuits, even if they constitute harmful, compulsive consumption and distribution of drugs, allow dislocated individuals to achieve a form of self-actualization (2001, p. 18). If this is the case for a pursuit laden with stigma in the Canadian context, how much more does work, which occupies a glorified position, have the capacity to function as a substitute lifestyle when exalted (Killinger, 1991, p. 7)?

In addition to connoting value, working enables us to establish an integral part of the identity of any postmodern individual: the con- 
sumer. While judging individuals according to their wealth is hardly a new social phenomenon, free-market society situates the possession of goods among the highest of virtues. In these circumstances, working more gives us more money to spend, and market growth ensures no end to potential new purchases. Crary characterizes the driving force in this process as "the portent of social and economic failure - the fear of falling behind, of being deemed outdated" (2013, p. 46). Significantly, he notes that the current demand for bigger and better is accompanied by a refashioning of "seemingly irreducible necessities of human life into ... financialized forms" (2013, p. 10). In other words, our environment of dislocation posits work not only as the fulfilment to our need for self-realization, but defines basic human needs like food and drink in such a way that makes us think we must meet them by working more than is actually necessary. As such, a workaholic lifestyle promises to meet all of our desires, as well as our needs.

\section{III: The Vicious CyCle}

Excessive work offers to relieve the worries growing from the hectic pace of postmodern life and the penetration of technology into every context; it promises status to soothe our troubled sense of self and to satisfy our desires. Over time, however, workaholism exacerbates these anxieties while leading to new sources of stress. For instance, although time can be harnessed to unhealthy amounts of work, increased job responsibility is accompanied by increased pressure. Analyst Leslie-Anne Keon comments in a study of Canadian work addicts that fears about time mobilize their addiction, noting that they perceive time management to be beyond their control (2008, p. 29). With no definite end to the opportunities for productivity and profit, those hooked on work may seek out new challenges on the job to increase their adrenaline rush from overworking (Griffiths, 2011, p. 744). Since work is positioned in a socially favourable light, exerting more effort becomes the answer to any dilemma (Oates, 1971, p. 13). As many work longer hours to stay on par with stan- dards of capital, the stress of consumer debt can manifest within homes and at a national level; paradoxically, a high benchmark for wealth can be used to justify longer work hours (Stearns, 2008, pp. 146, 159).

In response to this lack of psychosocial integration, choosing to work excessively perpetuates the detriment of the worker. Research shows that maintaining personal health is difficult when working long hours, even in the absence of an addiction to work. Large volumes of time spent sitting, the standard for many different kinds of work, is linked to increased risk of mortality (Diaz, et al., 2017, p. 465). The last frontier facing the free market is sleep; Caray characterizes this need to rest as an "intolerable affirmation that there might be limits to the compatibility of living beings with the allegedly irresistible forces of modernization" (2013, p. 13). Yet the amount of sleep we get is dwindling: "the average North American adult now sleeps approximately six and a half hours a night, an erosion from eight hours a generation ago, and (hard as it is to believe) down from ten hours in the early twentieth century" (2013, p. 11). Approximately $57 \%$ of working Canadians, many of whom report being overloaded with work, rate their stress levels as high. Only $23 \%$ of employees report high satisfaction with life, and over one third of them report a high level of depression (Duxbury \& Higgins, 2013, p. 12).

Furthermore, those with jobs often have to deal with the strain of caring for children or elderly parents, and can struggle to provide adequate support for their dependents (Duxbury \& Higgins, 2013, pp. 14). For example, working parents spend more time away from their children, fostering what psychologist Richard Grandpre labels a "culture of neglect"; he links this to the current spread of ADHD and Ritalin prescriptions (cited in Alexander, 2001, p. 12). These examples demonstrate that any conflict of interest with home life entails a myriad of implications for the psychosocial integration of other family members. No area of life remains 
untouched when the energy and time invested in work expand out of proportion to what is healthy for individuals and their relationships. Therefore, the consequences for individuals driven to work compulsively will be severe, as surpassing these healthy boundaries not only devastates their well-being but propels the furthered dislocation of those around them (Andreassen, Workaholism: An overview and current status of the research, 2013, p. 1; Ksiazak, 2014).

\section{IV: Conclusions}

In summary, working compulsively amidst a lack of stability and relationships in the postmodern world can be viewed as an attempt to mask our anxiety by protecting ourselves from vulnerability and garnering a sense of identity. In the end, however, addiction to work only perpetuates these fears and catalyses further dislocation. Although incompatibility with the demands of free-market society is the common experience of the postmodern individual, the status of work and the market forces that hold this status in place make it difficult for individuals to separate themselves from their employment long enough to assess their well-being (Stearns, 2008, p. 169). Ironically, because enormous commitments to work constitute the admission fee to the top of the capitalist hierarchy, the leaders of the free market are those the most controlled by it (Hassan, 2009, p. 114).

Given the prevalence of workaholism in Canada, it is notable that the data on this subject is sparse and collected in 2008, over ten years prior to the writing of this article. While the root causes of workaholism have not disappeared during this period of time, additional sources of stress to workers may have shifted or even intensified. For example, exponential developments in artificial intelligence may complicate workplace dynamics by jeopardizing employment (Kaplan, 2009, p. 3). Without recent and reliable data on addiction to work, Canadian citizens will not be able to address workaholism and its implications for their well-being, which may differ according to their cultural and socioeconomic backgrounds. Future investigations, therefore, would increase their accuracy through extending the depth of their qualitative analysis across the population, and are imperative next steps towards a healthier culture of work in Canada. Choosing to question our attitude of tolerance and even awe - of addiction to work may help us face our fears and start to relocate our relational bearings in space and time.

\section{Author Biography}

Anna Buhrmann is a second year student in the Arts \& Science program at McMaster University. Her curiosity is sparked by human ways of belonging and wellbeing, which she explores in the areas of global health, philosophy, history, language, and sociology. Following a class on the social roots of addiction she became interested in the connection between a lack of belonging and the recent broadening of the concept of addiction. She is grateful JIRR for an opportunity to engage with the concept of workaholism from an interdisciplinary perspective. 


\section{Works Cited}

Alexander, B. K. (2001). The Roots of Addiction in Free Market Society. Canadian Centre for Policy Alternatives.

Andreassen, C. S. (2013). Workaholism: An overview and current status of the research. Journal of Behavioural Addictions, 3(1), 11. DOI: 10.1556/JBA.2.2013.017

Andreassen, C. S., Griffiths, M. D., Hetland, J., \& Pallesen, S. (2012, April 20). Development of a work addiction scale. Scandinavian Journal of Psychology, 53(3), 265-272. https://doi.org/10.1111/j.1467-9450.2012.00947.x

Berlant, L. (2011). Cruel Optimism. Durham, NC: Duke University Press.

Centre for Intercultural Learning. (2018, -9 18). Cultural Information - Conversations. Global Affairs Canada. Retrieved from https://www.international.gc.ca/cil-cai/country_insightsapercus_pays/ci-ic_ca.aspx?lang $=$ eng

Clark, M. A., Michel, J. S., Zhdanova, L., Pui, S. Y., \& Baltes, B. B. (2016). All work and no play? A meta-analytic examination of the correlates and outcomes of workaholism. Journal of Management, 42(7), 1836-1873. doi: 10.1177/0149206314522301

Crary, J. (2013). 24/7: Late Capitalism and the Ends of Sleep. Brooklyn, NY: Verso.

Diaz, K. M., Howard, V. J., Hutto, B., Colabianchi, N., Vena, J. E., Safford, M. M., . . . Hooker, S. P. (2017, 10 3). Patterns of Sedentary Behavior and Mortality in U.S. Middle-Aged and Older Adults: A National Cohort Study. Annals of Internal Medicine, 167(7), 465-474.doi:10.7326/M170212 .

Duxbury, L., \& Higgins, C. (2013). Key Findings - Revisiting Work-Life Issues in Canada: The 2012 National Study on Balancing Work and Caregiving in Canada. Retrieved from https://newsroom.carleton.ca/wp-content/files/2012-National-Work-Long-Summary.pdf

Fong, F. (2018). Navigating Precarious Employment in Canada: Who is Really at Risk? Toronto, ON: Chartered Professional Accountants Canada. Retrieved from https://www.cpacanada.ca/en/ connecting- and-news/blogs/public-good/2018/january/a-very-precarious-situation

Griffiths, M. D. (2011). Workaholism - a 21st-century addiction. The Psychologist: Bulletin of the British Psychological Society, 24(10), 740-744. Retrieved from https://www.academia.edu/429387 /Griffiths_M.D._2011_._Workaholism_A_21st_century_addiction._The_Psychologist_Bulletin_of_the _British_Psychological_Society_24_740-744

Hassan, R. (2009). Empires of Speed: Time and the Acceleration of Politics and Society. Leiden, The Netherlands: Koninklijke Brill NV.

Kaplan, J. (2015). Humans need not apply: a guide to wealth and work in the age of artificial intelligence. Retrieved from https://ebookcentral.proquest.com 
Keown, L.-A. (2008). Time escapes me: Workaholics and time perception. Canadian Social Trends. Statistics Canada. Retrieved from https://www150.statcan.gc.ca/n1/pub/11-008-x/2007001/pdf /9629-eng.pdf

Killinger, B. (1991). Workaholics: The Respectable Addicts. Toronto, ON: Key Porter Books Limited.

Ksiazak, T. (2014). Work addiction. Salem Press Encyclopedia of Health. Retrieved from http://libacc ess.mcmaster.ca.libaccess.lib.mcmaster.ca/login?url=http://search.ebscohost.com/login.aspx?dire $\mathrm{ct}=$ true $\& \mathrm{db}=\mathrm{ers} \& \mathrm{AN}=94415588 \&$ site $=$ eds-live $\&$ scope $=$ site

Menzies, H. (2005). No Time: Stress and the Crisis of Modern Life. Vancouver, BC: Douglas \& McIntyre Ltd.

Oates, W. (1971). Confessions of a Workaholic. NY, NY: The World Publishing Company.

Polaski, S. (2004, May 30). Job Anxiety Is Real - and It's Global. Carnegie Endowment for Interna tional Peace, Washington, DC. Retrieved from https://carnegieendowment.org/files/Policybrief30.pdf

Ramsay, M. C., \& Lu, X.-A. L. (2013). Passive Addiction or Why We Hate Work: An Investigation of Problems in Organizational Communication. Lanham, MD: University Press of America, Inc.

Stearns, P. N. (2008). From Alienation to Addiction: Modern American Work in Global Historical Perspective. Boulder, CO: Paradigm Publishers.

Workaholics Anonymous. (2018). Welcome to Workaholics Anonymous. Workaholics Anonymous. Retrieved from http://www.workaholics-anonymous.org/index.php?page=home 